\title{
Implementation of the Dalton Plan Ideas into Ukrainian Alternative Schooling
}

\author{
Lolita Vorobiova \\ «PIHE «Zaporizhia Institute of Economics and Information Technologies» \\ Senior Lecturer
}

\begin{abstract}
The article deals with the first Ukrainian experience concerning the implementation of the components of the American pedagogical model of the Dalton Plan. The originator of The Dalton Plan and the founder of the prestigious Dalton School in New York was internationally known and honored for the contribution into the education. In Ukraine, the Dalton Plan had not been applied until 2017. It was pioneered by the alternative "DEC life school" in the city of Kiev. The DEC life school is based on the Dalton Plan, the Amonashvili School of Life and the Finnish curriculum. The characteristic feature of the Dalton plan can traced in tutoring accompaniment in teaching, which is provided by a teacher and addressed to each student individually. The dynamics of the implementation of the ideas of the Dalton Plan in the Ukrainian pedagogical space can be confidently characterized as a positive one.
\end{abstract}

Key words: individual education, Dalton Plan, Ukrainian educational system

The Dalton plan is the example of the implementation of reformation ideas in experimental pedagogy. The exposition of the principles and practices of education on the Dalton Plan was firstly held in New York on the basis of the whole school in 1919.

Helen Parkhurst, the originator of The Dalton Plan and the founder of the prestigious Dalton School in New York became internationally known and was honored for the contribution into the education in the countries such as the United Kingdom, the Netherlands, China and Japan (Parkhurst, 1949), (Parkhurst, 1957).

The invented 100 years ago efficient teaching system is to reorganize the physical and social structure of a school. The original model of the Dalton plan is based on three critical components. They are The Assignment, The Laboratory and The House. The Dalton-plan mainstay is individual work by the plan got from the teacher, which includes assigned tasks and references on the sources to fulfill them both in the laboratory and at home (Glendon, 1955:20).

At the beginning of the $20^{\text {th }}$ century the ideas of the Dalton Plan were eventually spread throughout Europe. Dalton pioneered in the Soviet Union as well. The Dalton Laboratory Plan (later transformed into "the brigade-laboratory method") was implemented in the wide 
range of schools such as secondary schools, party schools, high party schools, military schools, evening schools for workers, political courses, "work faculties" ("RabFaks") and faculties of the pedagogical educational establishments (Simonov, 1926:195).

However, the "brigade-laboratory method" was negatively estimated and criticized. The reasons are based upon the non-correspondence of individualism as the basic Dalton Plan principle with the collectivism, as one of the main concepts in the soviet education. And it was forgotten by the Ukrainian and Russian educators for more than 80 years.

Nowadays, in the context of the Ukrainian reforms in the field of education, many educators, philosophers and psychologists fall back on the pedagogical experience dated back to the beginning of the last century. Persecution of the strategic goals related to the educational reform requires the Ukrainian educators to be aware of the background for the formation of the qualitative teaching and learning methods in order to implement them into Ukrainian schooling.

In Ukraine at the present stage of education development an alternative "school" has been arisen as the format of an educational institution. In fact, such institutions offering alternative programs or forms of study have not obtained yet the status of a school. According to the Ministry of Education and Science of Ukraine (https://mon.gov.ua) at this reforming stage of the Ukrainian education such alternative educational institutions do not have state registration, because the registration mechanism is nearly non-existent.

Although there are reforms in Ukraine, but they are being adopted on the sidelines of the base form of study without offering the variety of forms to organize the educational process it. The main form of study still remains class-and-lesson system. So, alternative schools, regardless of their format, conclude agreements with general educational institutions. The latter are allowed to conduct distance learning and also to provide their graduates with state-issued documents about the relevant educational or education and qualification

level.

In Ukraine, the Dalton Plan had not been applied until 2017. It was pioneered by the alternative "DEC life school" (Development, Education \& Culture) in the city of Kiev.

According to N. Tarchenko, the originator of DEC life school, the idea of opening an alternative school led to an understanding that the training in public schools "became obsolete and sometimes absurd" (Tarchenko, 2017, p.61). The founder of DEC life school 
sees three major drawbacks of a modern Ukrainian school. First, a subjective assessment system based only on the teacher's mind, injures and affects the child's self-esteem, and becomes a definite label. Secondly, there is the mismatch of the curriculum with the realities of the present. Students get knowledge that does not come in handy in adulthood. Thirdly, in Ukrainian state schools there is the mechanical assimilation of the material, the lack of the process of forming students' own attitude and the ability to debate or to formulate or express their own thoughts.

The alternative DEC life school practises an individual form of education on the base of Private educational institution "Optima Education Center" for providing educational services in the field of general secondary education (providing basic general secondary education, providing full secondary education) in Kyiv. The Center carries out the educational process on the distance learning form.

The Dec life school initiated the first recruitment of full time students aged 6-12 in September 2017.

The DEC life school is based on the Dalton Plan, the Amonashvili School of Life and the Finnish curriculum. The latter has been chosen as the basis for the school, since it is based on the development of important competences, which compose the ability and motivation to study, creativity and critical thinking.

The Dalton Plan is traced in the planning of individual learning curriculum, in the training to cooperate with both teachers and other students. According to H. Parkhurst the Dalton school was to become a social laboratory. The educators of the DEC life school believe that it was created a model of a real society, where students learn to interact and communicate on an equal basis regardless of age. The characteristic feature of the Dalton plan can be also seen in tutoring - accompaniment in teaching, which is provided by a teacher and addressed to each student individually.

Another significant point is that the practical experience of introducing the DaltonPlan methodology is shared by Polish colleagues. They also organize the training of Ukrainian teachers. 
In summing up it can be said that the analysis of the Ukrainian alternative DEC life school shows that the Dalton Plan was adapted to the national educational system of Ukraine. By tracing the dynamics of the implementation of the ideas of the Dalton Plan in the Ukrainian pedagogical space, we can confidently characterize it as a positive one.

\section{References}

Glendon, M. (1955, September 7). When Dalton pioneered. The Berkshire Eagle, p.20

Merzon, I. (1925). Daltonskii laboratornyi plan v russkoi shkole [Dalton Laboratory plan in Russian school]. Moscow: Rabotnik prosveshcheniia [in Russian].

Parkhurst, H. (1957). Memorabilia [the Order of the Oranje-Nassau (medal with case)]. Helen Parkhurst Papers (Collection 5, Box 14), University of Wisconsin Stevens Point Archive, Stevens Point, WI.

Parkhurst, H. (1949). Memorabilia [The 13 ${ }^{\text {th }}$ American Exhibition of Educational Radio Programs Award]. Helen Parkhurst Papers (Collection 5, Box 17), University of Wisconsin Stevens Point Archive, Stevens Point, WI.

Simonov, I.S. (1926). Kratk.obzor noveishei literatury po D.-Planu [Brief review of latest literature about Dalton Plan]. Dalton Plan v russkoi shkole- Dalton Plan in Russian school, 2, 192-200 [in Russian].

Siropolko, S. (2001). Istoria osvity v Ukraini [History of education in Ukraine]. Kyiv:Nauk.dumka [in Ukrainian].

Tarchenko, N., \& Tarchenko O. (2017). Maibutnie tvorytsia siogodni [Future is being created today]. Edventure, 10, 6-9 [in Ukrainian].

Ministry of Education and Science of Ukraine (https://mon.gov.ua)

The DEC life school (http://www.declifeschool.com) 